\title{
МЕЖДУНАРОДНОЕ МОЛОДЕЖНОЕ И СТУДЕНЧЕСКОЕ ДВИЖЕНИЕ: ЭТАПЫ БОЛЬШОГО ПУТИ
}

\author{
И. А. Володин \\ Московский гуманитарный университет
}

Аннотация: В статье делается исторический обзор деятельности международного молодежного и студенческого движения в мире.

Ключевые слова: молодежное движение; студенческое движение; история; молодежь; Коммунистический интернационал молодежи

\section{INTERNATIONAL YOUTH AND STUDENT MOVEMENT: STAGES OF A BIG JOURNEY}

\author{
I. A. Volodin \\ Moscow University for the Humanities
}

Abstract: The paper gives a historical review of the activities of the international youth and student movement in the world.

Keywords: youth movement; student movement; history; youth; Young Communist International

Организованное молодежное движение появляется на определенном этапе общественного развития, что было во многом связано с осознанием растущей значимости проблемы подрастающего поколения и его воспитания в духе господствующей морали и системы ценностей.

Большое внимание работе с молодежью уделяла церковь. В середине XIX в. под ее эгидой создаются первые юношеские христианские общества и их оформление в единую организацию - Христианский союз молодых людей (ХСМЛ) - Young Men`s Christian Association (YMCA). Появившись в 1844 г. в Лондоне христианское молодежное движение стало быстро развиваться, и к началу XX в. оно распространило свое влияние практически во всех странах Европы, странах Азии и Африки, Латинской Америки, в Соединенных Штатах Америки и Австралии. Параллельно с Христианским союзом молодых людей возникает и развивается Христианский союз молодых женщин (ХСМЖ) - Young Women's Christian Association(YWCA), цели и направления деятельности которого были весьма близки тем, которые ставил ХСМЛ. В 
Научные труды Московского гуманитарного университета 2018 № 6

1855 г. во Франции состоялась первая всемирная конференция ХСМЛ, на которой было официально объявлено о появлении новой международной христианской молодежной организации, основанной на федеративных принципах управления, и принят главный документ ХСМЛ - «Парижский статут» (Paris Basis). Союз представлял собой независимую самоуправляющуюся организацию, существовавшую за счет пожертвований и сборов от различных мероприятий, а также членских взносов. В основе всей деятельности Союза лежала христианская духовно-нравственная и просветительская работа. Кроме того, отдельные союзы ставили перед собой частные задачи, такие, например, как предоставление приюта одиноким молодым людям - соотечественникам или иностранцам; объединение молодых людей-христиан, независимо от церквей, с целью общей христианизации молодежи и т. д. Примерно в это же время в США и Англии одновременно появляется Студенческое христианское движение, ставившее своей целью объединение студентов всего мира и воспитание их в духе христианской морали. Оформившись в конце XIX века в международную организацию Всемирный христианский студенческий союз (ВХCC), оно стало частью международной организации ХСМЛ. ВХСС позиционировал себя как международную межконфессиональную организацию на федеративных началах. Деятельность ХСМЛ и ВХСС строилась на принципе уважения национальной и религиозной самобытности стран и входящих в их состав союзов.

На рубеже XIX и XX веков появляются и первые пролетарские молодежные организации. Их возникновение было связано с широким распространением в мире идей социализма, бурным развитием рабочего движения. Созданию социалистических союзов рабочей молодежи способствовала деятельность II Интернационала. Эти объединения проявили стремление к международному объединению, которое поддерживалось левыми социал-демократами. В августе 1907 г. в Штутгарте была созвана Первая международная конференция молодежи, на которой были представлены союзы молодежи 13 стран Европы. Именно Штутгартская конференция постановили создать международное объединение социалистических молодежных организаций. Центральным направлением деятельности социалистической молодежи была антимилитаристская пропаганда.

Правящие круги западных стран усмотрели серьезную опасность в организациях социалистической молодежи и повела яростное наступление на молодых антимилитаристов. В 1908 г. рейхстаг Германии принял закон, запрещавший молодежи до 18 лет вступать в какие-либо союзы и организации и посещать политические собрания. Социал-демократическая партия Германии и профсоюзы капитулировали перед правительством. В том же году профсоюзы, а затем и партийный съезд СДПГ приняли решение о ро- 
спуске союзов молодежи Германии. Примеру СДПГ последовали соцпартии других стран.

Начавшаяся 1 августа 1914 г. Первая мировая война явилась тяжелым испытанием для международного движения социалистической молодежи. Вожди большинства социал-демократических партий и 11 Интернационала вслед за своими правительствами провозгласили лозунг «защиты отечества». Всеобщий угар национализма охватил широкие массы молодежи Германии и Франции, Австрии, Бельгии, Голландии. Но большинство секций, примыкавших накануне войны к Интернационалу молодежи, не изменили своей антимилитаристской позиции. Среди них были социалистические юношеские организации Италии, Швейцарии, Швеции, Норвегии, Дании, Болгарии.

Таким образом, международное движение пролетарской молодежи с началом войны оказалось расколотым, что резко снижала его возможности противостоять националистическим и шовинистическим тенденциям. В этих условиях большевики и поддерживавшие их левые социалисты выступали с лозунгами широкой пропаганды социалистической революции и превращение империалистическую войну в гражданскую, борьбы против социал-шовинизма, за создание нового пролетарского революционного Интернационала. Осуществление этих целей было достигнуто в 1917 г. в результате революции в России, приведшей большевиков к власти.

Непосредственное влияние революции в России на международное молодежное движение проявилось в создании коммунистических союзов молодежи. Уже в 1918 г. возникли три такие организации: в августе был создан Коммунистический союз молодежи Финляндии, в октябре - Российский комсомол, ноябре - Союз коммунистической рабочей молодежи Австрии.

Процесс консолидации революционной молодежи получил мощный импульс после образования в ряде стран Европы коммунистических партий и образования в марте 1919 г. по инициативе В. И. Ленина Коммунистического Интернационала. Интересы дальнейшего развития мирового революционного процесса, как это виделось левым силам в тот период, требовали сплочения пролетарской молодежи на новой основе, что нашло свое отражение в создании Коммунистического Интернационала Молодежи (КИМ).

Ведущую роль в создании КИМа принадлежала Российскому комсомолу, представители которого входили в комиссию Исполкома Коминтерна и вели активную работу по подготовке программы и устава КИМа. Учредительный съезд КИМа состоялся в Берлине в ноябре 1919 г и проходил нелегально. Принятая конгрессом программа КИМа нацеливала молодежь на борьбу с капитализмом, против «буржуазного милитаризма», но «за воору- 
Научные труды Московского гуманитарного университета 2018 № 6

жение пролетариата, за Красную Армию».

Деятельность КИМа проходила в весьма сложных условиях. Курс на свержение буржуазного строя не встречал широкой поддержки в молодежи. Социал-реформистские молодежные объединения, особенно находившиеся под эгидой социал-демократических партий, взяли курс на раскол рядов рабочей и студенческой молодежи. В 1921 г. были созданы сразу два социал-реформистских объединений: правосоциалистический Интернационал Рабочей Молодежи (ИРМ, II Интернационал молодежи) и центристское Международное объединение социалистических юношеских организаций, или, как его называли II 1/2 Интернационала молодежи. Вслед за своими идейными наставниками они взяли курс на противодействие революционной деятельности молодежи в своих странах и на международной арене.

Серьезным препятствием на пути сплочения широких масс молодежи были и сектантские тенденции в рядах в рядах членских организаций КИМа. Они находили отражение прежде всего в «юношеском авангардизме», сторонники которого считали рабочую молодежь самой активной частью пролетариата и в этой связи отводили ее организациям руководящую роль в революционном движении, стремились действовать независимо от компартий, параллельно с ними решать общеполитические вопросы. Как и руководители молодых компартий, переживавшие в тот период детскую болезнь «левизны», авангардисты недооценивали работу в массах, отвергали компромиссы и соглашения с молодежными организациями других политических направлений, выступали против участия в «реакционных профсоюзах», использования трибуны «буржуазного парламента» в революционных целях и не уделяли достаточного внимания вопросам организации борьбы за улучшение экономического положения трудящей молодежи, идейно-воспитательной и культурно-просветительной работе.

Этот авангардистский заряд серьезно подрывал усилия революционных молодежи с организациями других политических направлений, которые не разделяли ее революционную идеологию и стояли на позициях реформизма. С учетом этих различий вполне естественным выглядел их отказ от совместных действий, стремление обособиться, вести свою деятельность самостоятельно, что нашло свое выражение в объединении в 1923 г. двух интернационалов в единый Социалистический Интернационал Молодежи (СИМ). Однако положение стало меняться в условиях разразившегося в 1929-1933 гг. глубокого экономического кризиса и наступления фашизма в ряде европейских стран. В сентябре 1933 г. в Париже прошел мировой конгресс молодежи против войны и фашизма, участие в котором приняли не только молодые коммунисты, но и социал-демократы, молодые христиане и юноши других взглядов и убеждений. 
Движение антифашистского единства охватило большинство европейских стран. Наиболее сильным оно было во Франции. Здесь повсюду стали возникать антифашистские комитеты молодежи, в состав которых входили комсомольцы, социалисты, республиканцы, члены религиозных юношеских организаций. Важную роль в мобилизации молодежи различной политической ориентации сыграли Международный антивоенный конгресс студентов (Брюссель, 1934), Международная конференция молодежи за мир, свободу и прогресс (Париж, 1935), а также деятельность Международного бюро по подготовке интернационального слета молодежи.

По мере роста опасности фашизма и войны лидеры СИМа начали менять свое отношение к КИМу, единому фронту с ним. Эта тенденция заметно усилилась после VII Конгресса Коминтерна, выработавшего курс на объединение самых широких слоев молодежи для борьбы против фашизма, милитаризма, за их экономические и культурные интересы. Конгресс рекомендовал КИМу создавать с социал-демократическими юношескими организациями антифашистские ассоциации на платформе классовой борьбы.

Тенденция к единству уверенно пробивала дорогу и в международном студенческом движении. Проходивший в 1936 г. в Оксфорде конгресс Социалистического Интернационала студентов принял решение об объединении со студентами-коммунистами. А через год в Париже состоялся совместный конгресс социалистического и коммунистического студенчества. Его делегаты, прибывшие из 24 стран, основали Международный студенческий альянс борьбы за социализм, который потом поддерживал связи с КИМом и СИМом, выступа за единство их действий.

Определенные сдвиги в интернациональном сплочении антифашистского юношеского движения были достигнуты на первом Всемирном конгрессе молодежи (Женева, 1936). В работе этого форума участвовали 760 представителей национальных организаций 36 стран и 16 международных юношеских объединений. Участники конгресса единодушно высказались за единство действий юношей и девушек разных взглядов и убеждений.

Движение молодежи за мир, получив мощный импульс на Женевском конгрессе, способствовало сближению лидеров КИМа и СИМа. В июне 1937 г. в Испании состоялось совещание представителей этих организаций, в ходе которого была достигнута договоренность о единстве действий в поддержку испанской молодежи, сражавшейся вместе со старшим поколение с оружием в руках против фашизма. Во, Франции, в Италии, Югославии, Греции и ряде других стран возникли демократические союзы молодежи, которые объединили различные по политическим взглядам и социальному положению группы юношей и девушек. Общим для членов этих организаций было стремление покончить с фашизмом. 
Научные труды Московского гуманитарного университета 2018 № 6

Развязанная в сентябре 1939 г. Вторая мировая война вызвала глубокие сдвиги в массовом сознании молодежи, результатом которых стало вовлечение в активную политическую борьбу растущего числа юношей и девушек, которые в прошлом не проявляли активности, придерживались аполитичных взглядов. Особую активность в этот период проявила студенческая молодежь. В октябре-ноябре 1939 г. в Праге состоялась первая антифашистская демонстрация студентов. Студенческие выступления были жестоко подавлены гитлеровцами: 17 ноября 9 руководителей студенческих организаций были расстреляны, 1200 учащихся были отправлены в концентрационный лагерь Заксенхаузен. Осенью 1940 г. возникает движение французских студентов против фашисткой оккупации и режима Виши (Ouzoulias, 1967). В ноябре, в год годовщины пражских событий, в Париже состоялись массовые антифашистские демонстрации студентов, ставшие «первыми крупными выступлениями против гитлеровских захватчиков» во Франции (Le Parti communiste francais ... , 1962). По мере продолжения войны и расширения гитлеровской агрессии антифашистское молодежное движение разрасталось. В сентябре 1942 г., в разгар ожесточенных боев Красной Армии с немецко-фашистскими захватчиками под Сталинградом в Вашингтоне состоялся Международный конгресс студентов, в котором, наряду с представителями молодежных организаций 53 стран, приняла участие и делегация Антифашистского комитета советской молодежи (АКСМ). Конгресс был организован Американским комитетом Международной студенческой службы, пользовавшим покровительством американской администрации. Примечательно, что устроители конференции рассчитывали придать ей культурно-просветительный характер, исходя из расхожего в то время тезиса, что политика - дело государственных деятелей и дипломатов, а не молодежи (Михайлов, 1980: 43). Тем не менее, политические вопросы, в первую очередь насущные задачи борьбы с фашизмом, заняли центральное место в дискуссиях на конференции. Принятая конференцией декларация призывала студенческую молодежь активно содействовать борьбе народов за полный разгром фашизма, в поддержку открытия второго фронта в Европе. «Победа, говорилось в Вашингтонской декларации, - должна означать право народов, независимо от расы, цвета кожи или убеждений, выбирать свою собственную политическую систему...» (Constitution of the ... , 2). Важнейшим итогом конференции стало учреждение нового интернационального объединения - Международной студенческой ассамблеи (МСA), призванной координировать совместные действия демократических студенческих организаций разных стран. Спустя два месяца, в ноябре 1942 г., в Лондоне была созвана Международная конференция демократической молодежи, которая знаменовала дальнейший шаг на пути консолидации 
юношеских организаций различной политической ориентации. Участники конференции выразили солидарность с советским народом и призвали молодежь мира включаться в борьбу против общего врага - фашистской Германии и ее союзников. С целью координации действий национальных молодежных организаций, обмена опытом и информацией был учрежден Всемирный Совет Молодежи (ВСM). Работавшая в рамках лондонской конференции студенческая комиссия приветствовала этот факт как «большой шаг вперед в развитии международного студенческого движения». «Мы имеем теперь возможность, - говорилось в заключительном документе комиссии, - связать воедино международное студенческое движение в США Великобритании и Советском Союзе, что будет значительно способствовать нашей общей борьбе» (Youth and ... : 13).

С созданием ВСМ и МСА явственно обозначились контуры единого общедемократического фронта молодежи - рабочей и студенческой. Но на этом пути с самого начала выявились серьезные ограничители. Их суть состояла в том, что в руководстве МСА верх взяли традиционные аполитичные взгляды на роль и место учащейся молодежи в обществе. Лидеры МСА, выступая на словах за объединение демократической молодежи в борьбе с фашизмом, на деле оставались практически безучастными к призывам ВСМ развивать конкретные акции. Пассивность руководства МСА, не способствовавшая расширению ее связей со студентами стран антигитлеровской коалиции, вызывала серьезное недовольство национальных студенческих организаций, особенно тех, кто активно действовал в рамках ВСМ. Левые силы в странах антигитлеровской коалиции, извлекшие серьезные уроки из своих ошибок сектантского характера в межвоенный период, активно стремились закрепить эту тенденцию в международном молодежном движении. Именно с учетом этого тренда было принято решение о роспуске в мае 1943 г. о роспуске КИМа.

Разгром фашизма и окончание Второй мировой войны положило начало новому этап в развитии международного молодежного и студенческого движения, характерной особенностью которого стало сотрудничество молодежи различной политической ориентации в рамках интернациональных объединений. В ноябре 1945 г. в Лондоне Всемирная конференция молодежи учредила Всемирную федерацию демократической молодежи (ВФДМ). Ее девиз «Молодежь, объединяйся в борьбе за мир, демократию, национальную независимость и лучшее будущее!»

Создание ВФДМ дало заметный импульс процессу организационного сплочения международного демократического студенческого движения. В ноябре 1945 г. в Праге собрался Всемирный конгресс студентов. Он был задуман как торжественный форум, посвященный антифашистским высту- 
Научные труды Московского гуманитарного университета 2018 № 6

плениям пражских студентов 1939 г. Однако он вышел за эти рамки, став важной вехой на пути создания новой международной организации Международного союза студентов (МСC). Приветствуя учреждение ВФДМ, участники конгресса заявили о своем стремлении установить «прочное сотрудничество и дружбу с демократической молодежью во всем мире» (ЦА ВЛКСМ, ф. АКСМ, д. 837, л. 18). Учредительный конгресс МСС состоялся спустя год, в августе 1946 г в Праге. На нем были представлен весьма широкий спектр студенческих организаций из 38 стран мира - от чисто политических до религиозных. По этой причине наблюдались серьезные различия и в их взглядах на характер создаваемой организации и ее роль и место на международной арене. Подавляющая часть участников, которых причисляли к лагерю прогрессивных сил, выступали за создание такого международного центра, который объединял бы все демократические студенческие организации на широкой платформе борьбы за мир, национальное освобождение, в защиту прав и интересов учащейся молодежи. Они исходили из того, что имеющиеся политические и другие различия в международном демократическом студенческом движении не могут служить непреодолимым препятствием на пути к такому объединению. Это вывод базировался на учете имеющегося опыта сотрудничества студенчества различной политической ориентации в годы совместной борьбы с фашизмом.

Идеалом консервативных участников, выступавших с «аполитичных» позиций, являлась корпоративная организация, призванная заниматься «чисто студенческими» проблемами. Их позиция, пожалуй, наиболее точно была сформулирована в выступлении английского делегата: «Международный союз студентов может в том случае отражать интересы студентов всего мира, если он не будет входить в политические, религиозные и национальные разногласия, существующие в тех или иных странах, а будет сосредоточивать свое внимание на интересах, непосредственно касающихся студентов» (ЦА ВЛКСМ, ф. АКСМ, 1946, д. 610, л. 67). Корпоративисты настаивали на исключении из устава МСС термина «прогрессивный» ввиду того, что он «ассоциируется с принадлежностью к политическим партиям» (там же, л.12). Что касается практической деятельности будущей организации, то она должна была ограничиваться исключительно сбором и распространением информации.

Выступления корпоративистов, хотя и осложнили работу учредительного конгресса, не определяли в тот период общего настроя делегатов. Работа конгресса, характеризовавшаяся широкой тягой к единству, завершилось принятием устава и провозглашением новой организации, воплотившей в себе идеалы и чаяния демократического студенчества. Устав четко ориентировал студенчество на активное участие в общественно-политической 
жизни своих стран, в борьбе за решение кардинальных проблем послевоенного развития. «Демократические студенты, которые внесли свой вклад в разгром фашизма, - говорилось в резолюции конгресса, - должны также сыграть роль в устройстве послевоенного мира» (IUS Bulletin, 1946: 4).

Послевоенное устройство мира виделось, однако, на Западе и Востоке по-разному. Восток в лице СССР стремился «капитализировать» свои победы в войне против фашизма, выстраивая политические режимы в Восточной Европе по «советским лекалам» и поддерживая «прогрессивные антиимпериалистические» силы в других частях земного шара. Запад, столкнувшись с беспрецедентным геополитическим ростом авторитета и влияния Советского Союза и усмотрев в этом серьезную угрозу самому своему существованию, отошел от политики сотрудничества и взял курс на противодействие «советскому экспансионизму» по всему миру. Такой курс, разумеется, не мог осуществляться без идеологического «обоснования». И главными инструментами развернувшейся идеологической кампании стали «антикоммунизм» и «антисоветизм». Резонансной в этом отношении стала знаменитая речь в Фултоне отставного премьер-министра Великобритании У. Черчилля, который обвинил СССР в создании «железного занавеса», разделившего мир на две части. В мире она была воспринята как манифест «холодной войны».

Дух «холодной войны» был привнесен и в среду международного молодежного движения, который проявился в активизации консервативных и откровенно правых сил. Именно эти силы, выступая против продвигаемого ВФДМ «антиимпериалистического единства молодежи», попытались изменить характер ее деятельности. Получив отпор большинства членских организаций, они инспирировали выход из федерации целого ряда консервативных молодежных организаций Запада и образовали в 1948 г. раскольнического объединения - Всемирной ассамблеи молодежи (ВАМ). В студенческой среде критика антиимпериалистической платформы велась под флагом «защиты интересов студентов», которым-де угрожала эта платформа.

Так, на сессии Совета МСС в 1947 г. представитель НСС Швейцарии заявил, что его союз готов сотрудничать с МСС в обеспечении нужд студентов, но не может принять никакого участия в его деятельности в поддержку студентов и народов колониальных, полуколониальных или зависимых стран в их борьбе за свободу и независимость, так как подобные действия были бы несовместимы с их принципами сохранения нейтралитета (ЦА ВЛКСМ, ф. АКСМ, 1947, д. 853, л. 197). С «аполитичных» позиций выступал и голландский делегат, утверждавший, что введение политики в студенческую жизнь воздвигнет барьеры, ведущие к расколу студенческих организаций и к отвлечению их внимания от вопросов, касающихся их как студентов 
Научные труды Московского гуманитарного университета 2018 № 6

(там же, д. 973, л. 143). На этом основании он потребовал пересмотра устава MCC, который, по его словам, противоречит их подходу и «обязывают каждого студента в мире своими решениями, принимающимися простым большинством голосов без обсуждения в различных странах» (там же, л. 94). Требования «деполитизации» МСС путем ревизии его устава не получило поддержки большинства членских организаций. Потерпев неудачу в своих планах столкнуть МСС с активной антиимпериалистической позиции и превратить его в корпоративную организацию, консервативные студенческие лидеры западных стран встали, как и в случае с ВФДМ, на путь открытой борьбы с ним.

В 1948 г. правые спровоцировали выход из МСС ряда западных студенческих союзов. Однако они не могли сразу создать раскольническую организацию, ибо в МСС остались два влиятельных объединения - НСС Великобритании и Франции. К тому же и в США эта идея не находила в тот период поддержки у руководителей Национальной студенческой ассоциации, где все еще были сильны настроения в пользу сотрудничества в рамках МСС. Однако с усилением «холодной войны», эти настроения пошли на спад. В этой атмосфере правым студенческим лидерам удалось добиться выхода НСС Франции из МСС. Вслед за этим правые взяли верх в студенческом союзе Великобритании: в 1950 г. они провели решение о приостановке членства в МСС национального студенческого союза. В том же году раскольнические организации провели в Стокгольме сепаратную международную студенческую конференцию, которая учредила специальный комитет, на который возлагалась задача «изучить необходимость и желательность, финансовые возможности и структуру нового международного союза» (World Student News, 1951: 5). Выяснилось, что лидеры раскола преследовали отнюдь не «аполитические» цели. Президент НСА США призвал студентов «учиться стать эффективными борцами против коммунизма, указав на то, что созданный комитет должен «направлять и координировать» всю работу в этом духе в Латинской Америке, Азии и Африке (там же: 17). Достижению этой цели была призвана служить и принятая конференцией программа помощи «демократическим» студенческим организациям в этих регионах. Это была своего рода программа «четвертого пункта» президента Трумэна для студентов. В ней отражалось стремление правящих кругов США поставить новую международную студенческую организацию на службу американского внешнеполитического курса. Не удивительно, что с учреждением в 1952 г. постоянно действующего Координационного комитета Международной студенческой конференции новая раскольническая организация МСК-КОСЕК активно включилась в антикоммунистическую и антисоветскую кампанию. 
Политическая линия МСК и его руководящего органа - КОСЕК весьма четко просматривалась в связи с их отношением к военным авантюрам западных стран в Корее, во Вьетнаме, на Ближнем Востоке и ряде других регионов мира. Они не вызвали ни малейшего протеста у МСК. Наоборот, лидеры МСК делали все возможное для того, чтобы помешать студенчеству высказаться по этим животрепещущим вопросам, ссылаясь на то, что эти проблемы не входят в компетенцию студенческих объединений.

Но и в «чисто студенческой» сфере деятельность МСК-КОСЕК оказалась практически незаметной, что весьма скоро стала вызывать серьезное недовольство целого ряда студенческих союзов. Так, на конференции в Стамбуле (1954) французская делегация подвергла резкой критике пассивность лидеров МСК в этом вопросе, заявив, что «практическая деятельность КОСЕК абсолютно не соответствует надеждам его учредителей» (World Student News, 1954: 13). Еще более критический взгляд на деятельность МСК-КОСЕК формировался в студенческих организациях Азии, Африки и Латинской Америки, многие из которых рассматривали ее как проводника «холодной войны» в международном студенческом движении. В этих организациях прежде всего встречали позитивный отклик инициативы МСС и ВФДМ по развитию сотрудничества и совместных действий.

В конце 1950-х годов НСС Франции и Союз польских студентов выступили с предложение о проведении встреч студенческой молодежи Европы. Первая из таких встреч состоялась в Париже, положив начало ежегодным студенческим форумам, длившимся более трех десятилетий. Интересно отметить ту эволюцию, которую прошли эти встречи в содержательном плане. На первых порах они не выходили за рамки «чисто студенческих» проблем. Однако в последующем по причине усиления активности студентов Запада, в ходе которой стали выдвигаться весьма широкие социально-политические требования, попытки правых сил оградить студенчества от обсуждения актуальных проблем общественного развития оказались обречены на провал.

Более того, под напором студенческой борьбы сама МСК и ее руководящий орган - КОСЕК были вынуждены претерпеть определенную трансформацию: они отходят от неприкрытой апологии «свободного мира», отказываются от традиционного аполитического принципа «студент как таковой» и пытаются даже перехватить некоторые антиимпериалистические лозунги левого студенчества. В то же время они по-прежнему выступали против любых совместных действий с МСС. Это особенно наглядно проявилось в подходе КОСЕК к предложению о проведении конференции «круглого стола», выдвинутого Федерацией университетских студентов Уругвая. Не решаясь открыто отвергнуть саму идею, которую поддержала целая группа членских организаций МСК, правые лидеры попытался оттеснить МСС, навязав боль- 
Научные труды Московского гуманитарного университета 2018 № 6

шинству решение о проведении конференции под эгидой КОСЕК. Стремясь обезопасить себя и продемонстрировать внушительную поддержку своему курсу, КОСЕК доставил на конференцию «делегации» эмигрантских и раскольнических групп из целого ряда латиноамериканских стран. Была приглашена даже франкистская студенческая организация СЕУ. В то же время были предприняты все усилия, чтобы не допустить на конференцию прогрессивную студенческую организацию Пуэрто-Рико. Все это вызвало возмущение широкого круга участников. 27 делегаций в знак протеста покинули конференцию, среди них были весьма авторитетные и влиятельные студенческие союзы Латинской Америки, Африки, Азии и Европы.

Эти союзы выступали за развитие международного студенческого сотрудничества, в поддержку конференции «круглого стола». В 1962 г. конференция студентов стран Магриба предложила провести в Тунисе международный семинар с участие студенческих организаций, входящих в МСК и МСС. Организаторы семинара предполагали обсудить специальную тему: «Структура международного студенческого движения и средства достижения всеобщего сотрудничества». Идею тунисских студентов поддержал МСС и целый ряд студенческих организаций, входивших в МСК. В этих условиях лидеры МСК были вынуждены принять участие в семинаре. Однако работа семинара показала, что целью было не поиски путей взаимодействия студенчества различных стран, а, наоборот, помешать конструктивному обсуждению избранной темы, используя для этого свою излюбленную тактику - процедурные манипуляции. Когда же стало ясно, что сорвать работу семинара не удастся, то они покинули семинар.

Семинар в Тунисе стал наглядным свидетельством нарастающей изоляции правых в международном студенческом движении, где все увереннее пробивала себе дорогу тенденция к сотрудничеству по важнейшим вопросам мировой политики, в защиту интересов и прав учащейся молодежи. Одновременно укреплялся авторитет МСС, проводивший неизменный курс на сплочение широких масс студенчества в борьбе за решение кардинальных проблем международного развития, в том числе реформу и демократизацию образования. В 1960 г. в ряды МСС вступил целый десяток национальных студенческих союзов Африки и Латинской Америки. Спустя два года членами МСС стали еще 15 студенческих организаций, в том числе два студенческих союза Бельгии.

Напротив, массовая база МСК стала заметно сужаться, что создавала опасность потерять всякое влияние в международном студенческом движении. Сознавая шаткость своего положения, КОСЕК решил прибегнуть к радикальной реформе. В 1964 г. на конференцию в Крайстчерче (Новая Зеландия) не были допущены «взбунтовавшиеся» союзы, покинувшие пре- 
дыдущую конференцию, что позволило правым лидерам протащить устав МСК, который превратил ее из аморфной структуры в централизованную организацию с широкими полномочиями исполнительных органов и жесткими условиями приема, открывающими реальные возможности поставить заслон перед неугодными с политической точки зрения организациями. Примечательно, что в исполнительные органы МСК избирались не организации, как это принято в демократических международных организациях, а индивидуальные лица «из среды квалифицированных студенческих лидеров, ...исходя из их компетентности и приверженности принципам МСК, определенным в ее уставе» (The Student, 1964: 12). Все это было нацелено на то, чтобы максимально ограничить влиянии членских организаций на формирование политического курса МСК, ее практическую деятельность. Вся полнота власти в МСК в период между конференциями оставалась по-прежнему в руках, по сути, назначаемой группы все тех же правых студенческих лидеров. Маневры лидеров МСК тем не менее не дали желаемых результатов. Конференция в Крайстчерче была заклеймена подвергшимися репрессивным мерам студенческими организациями как раскольническая акция, призванная помочь правым студенческим лидерам сохранить свое господствующие позиции в МСК. В ответ два десятка студенческих союзов - членов МСК вступили в ряды МСС. Среди них были весьма крупные и авторитетные объединения Франции, Бразилии, Греции, Перу и целого ряда других стран. Недовольство позицией руководства МСК усиливалось и среди тех организаций, которые оставались в ее рядах. Особо острой критике подвергалась позиция КОСЕК в отношении агрессии США против Вьетнама. Не осмеливаясь открыто оправдать агрессора, лидеры МСК предпринимали попытки переложить вину за войну на Демократическую Республику Вьетнам, обвиняя ее в подрывной деятельности против Южного Вьетнама. Таким образом «обосновывался» категорический отказ КОСЕК поддержать требование значительного числа членов МСК о выводе американских войск из Вьетнама и заявить о своей поддержке справедливой борьбы вьетнамского народа (ЦА ВЛКСМ, ф.3, д.171, л. 123).

Такая двурушническая политика не могла сыскать уважения в студенческих организациях не только Азии, Африки и Латинской Америки, но и в странах Запада, где развернулись массовые движения протеста против войны США во Вьетнаме. Мощный удар по престижу нанесла публикация в 1967 г. материалов, изобличающих связи руководства МСК с Центральным разведывательным управлением США. Скандальное разоблачение, подтверждавшее существование тайного фронта борьбы реакции против прогрессивных сил в международном студенческом движении, окончательно дискредитировало МСК. После безуспешных попыток спасти лицо, правые 
Научные труды Московского гуманитарного университета 2018 № 6

лидеры должны были заявить о ее роспуске, признав, таким образом, свое полное политическое банкротство. Последнее было обусловлено, прежде всего, тем, что проводимый ими курс вошел в острое противоречие с господствующей тенденцией в международном студенческом и молодежном движении, отразившейся в небывалом росте социально-политической борьбы студентов в капиталистическом мире. Она объединила чрезвычайно широкий круг студенческих и молодежных организаций различной идейно-политической ориентации. Несмотря на имевшиеся различия в политических взглядах, они сумели найти формы совместных действий как в национальных рамках, так и в международном масштабе. Ярким свидетельством тому стало участие студенческих организаций мира в кампании солидарности с Вьетнамом, развернувшейся при содействии ВФДМ и МСС. Одной из заметных массовых форм сотрудничества стали Всемирные фестивали молодежи и студентов.

Вместе с тем нельзя не отметить и новые проблемы и трудности, которые возникли в этот период на этом пути. Они были связаны с политическими издержками в целом позитивного разрыва студенчества с буржуазно-либеральной политикой. «Недовольство ограниченностью буржуазно- либеральных целей борьбы подготовило почву для увлечения, хотя и кратковременного, ультралевыми взглядами. Разочарования в тактике ненасильственных действий породило среди студентов другую крайность - абсолютизацию насилия как формы борьбы», - отмечает советский исследователь С. Салычев (Левое ... , 1976: 20-21). Следствием такой эволюции стало усиление ультралевых тенденций в международном студенческом движении. С середины 1960-х годов заметно повысилась активность анархистских, троцาкистских, маоистских и других экстремистских организаций в студенческой среде в странах Западной Европы, Америки, Азии и Африки.

Ультралевые тенденции, проявившиеся и в членских организациях МСС, заметно осложнили проведение союзом линии на широкое международное сотрудничество и совместные действия студентов. Целый ряд членских организаций, абсолютизируя национальный опыт борьбы, попытался навязать его при выработке генерального курса деятельности МСС. На конгрессе МСС в Улан-Баторе (1967) левацкие лидеры ряда студенческих союзов Латинской Америки выступили против линии МСС на широкое сотрудничество и единство действий студентов в борьбе за решение кардинальных проблем современности, настаивали на том, что такое сотрудничество должно основываться на «революционных принципах». Они потребовали от МСС порвать всякие отношения с МСК и изгнать из него все организации, поддерживающие это объединение. «Проводить «широкую» политику в отношении таких организаций, - заявил делегат доминиканских студентов, - означает 
развивать плохое в МСС, в то время как необходимо отсечь его, чтобы оно больше не распространялось» (ЦА ВЛКСМ, ф. 3, оп.3, д. 244, л. 33). «Мы принимаем, - вторил ему представитель НСС Бразилии, — только возможность сотрудничества с организациями, придерживающимися одних с нами принципов» (там же, д. 391, л. 3). Абсолютизируя насилие, видя в нем единственно аффективный способ борьбы против империализма, за революционное переустройство существующего общества, левацкие лидеры добивались от MCC поддержки концепции «войны», а отказ от нее и поддержка принципов мирного сосуществования государств с различным общественным строем объявлялись ими предательством мирового революционного движения, сделкой с империализмом (там же, д. 244, л. 33).

Увлечение ультралевой политикой оказалось весьма кратковременной фазой развития студенческого движения. Уже в начале 70-х годов влияние многих левацких группировок, лидеры которых оказались неспособными предложить студенческим массам сколько-нибудь приемлемую, конструктивную программу действий борьбы за решение насущных проблем, резко упало. Одновременно отчетливо обозначился поворот в сторону конструктивного сотрудничества различных политических сил. Это не замедлило позитивно сказаться на отношениях студенческих организаций Запада с MCC. Важную работу со своей стороны проделал секретариат МСС, вынесший на очередной X конгресс членских организаций (1971 г.) конкретные инициативы и кампании, направленные на развитие совместных действий студенческих организаций по важнейшим направлениям студенческой борьбы, развернувшейся в 1970-е годы. Центральным направлением этой борьбы стало участие студентов в движении общественности за разрядку международной напряженности, безопасность и сотрудничество в Европе. Эта тенденция получила концентрированное выражение в совместной подготовке и проведении целого ряда широкопредставительных молодежных и студенческих форумов по вопросам европейской безопасности: Хельсинки (1970), Мюнхен (1970), Флоренция (1971), Хельсинки (1972). Успешное завершения Совещания по безопасности и сотрудничеству в Европе и подписание в 1975 г. в Хельсинки Заключительного акта способствовало распространению «духа разрядки» в международном молодежном и студенческом движении.

Новый импульс получила практика проведения политических консультаций с широким спектром молодежных и студенческих организаций, в том числе с рядом таких влиятельных объединений, как Международный союз молодых социалистов, Совет европейских национальных комитетов молодежи, Европейская федерация либеральной и радикальной молодежи, Международное молодежное и студенческое движение в поддержку ООН 
Научные труды Московского гуманитарного университета 2018 № 6

и др.. Они оказались особенно востребованными в обстановке нового обострения международной напряженности на рубеже 1970-1980-х годов. Однако эта тенденция подверглась серьезному испытанию с середины 1980-х годов в связи с фундаментальным изменением позиции руководства СССР, взявшего курс на «перестройку и гласность» во внутренней жизни страны и выстраивание отношений со странами Запада на основе общечеловеческих ценностей. На практике «общечеловеческие ценности» оказались западными, а стремление советского руководства преодолеть идеологическую и военно-политическую конфронтацию с Западом было расценено им как поражение СССР в «холодной войне».

Самороспуск Советского Союза и распад социалистического лагеря лишь укрепили лидеров западных стран в правильности их основного вывода. В атмосфере триумфа Запад во главе с США стал выстраивать свой новый миропорядок в основе которого лежат собственные геополитические интересы и представления о его характере и модели. В том же случае, когда в той или иной стране политический режим не соответствует этим представлениям или - тем паче - угрожает гегемонии лидера, то он подлежит «переформатированию» либо посредством силы, либо с помощью сценария так называемых «цветных революций». Именно такие сценарии были осуществлены сначала в Сербии, потом в Грузии (2003), на Украине (2004), в Киргизии (2005) и снова на Украине (2013-14). Главная цель всех этих «цветных революций» одна - изменить вектор развития упомянутых стран, замкнуть их ориентацию на Запад, подорвать интеграционные проекты, продвигаемые Россией. Во всех этих странах активную роль в реализации «революционных» сценариев сыграла молодежь, особенно студенческая. Ее акции получали щедрое финансирование, необходимое обучение, которое проводилось - в случае с Украиной - сербскими и грузинскими коллегами, а также некоторыми американскими фондами» (Арель, 2005: $41)$, - признает канадский исследователь «оранжевой революции» на Украине Доминик Арель.

Таким образом, во многих странах в условиях дестабилизации обстановки в целых регионах мира молодежь используется правящими кругами западных стран в качестве ударной силы либо так называемых «цветных революций», либо террористических организаций, как видно из событий последних лет на Ближнем и Среднем Востоке. Видя, как националистический угар уже отравляет сознание молодых людей на Украине и в ряде других стран, впору задуматься и вспомнить, как превращали германскую молодежь в бездумных исполнителей воли «фюрера» и куда эта дорога ее привела. Увы, европейские политики мало что делают для того, чтобы обуздать тот самый экстремизм, который сейчас расцветает пышным цветом 
во многих местах Европы. Они предпочитают из плитиканских соображений не видеть ни факельных шествий нацистских молодчиков, ни их зверств, ни других проявлений неонацизма.

\section{СПИСОК ЛИТЕРАТУРЫ}

17 ноября. Революционное движение чехословацкого студенчества (1945). Прага : Центр союз Чехословацк. студ-ва.

Constitution of the World Youth Council. Annex No 1. Declaration of Washington. S.l., s.a.

IUS Bulletin. Prague. 1946, October.

Le Parti communiste francais. La culture et les intellectuels (1962). Paris.

Ouzoulias, A. (1967) Les Bataillons de la jeunesse. Paris.

Youth and the Fight for Freedom. London, s.a.

Арель Д. (2005) Украина выбирает запад без востока // Pro et Contra. № 1 (28). С. 39-51.

Левое студенческое движение в странах капитала (1976). М. : Наука.

Михайлов, Н. (1980) На разных меридианах. М. : Детская литература.

Дата поступления: 30.08.2018 2.

Володин Иван Андреевич - кандидат исторических наук доцент кафедры международных отношений и дипломатии Московского гуманитарного университета. Адрес: 111395, Россия, г. Москва, ул. Юности, д. 5. Тел.: +7 (499) 374-75-31. Эл. адрес: intrelation@mosgu.ru

Volodin Ivan Andreyevich, Candidate of History, Associate Professor, Department of International Relations and Diplomacy, Moscow University for the Humanities. Postal address: 5, Yunosti St., Moscow, Russian Federation, 111395. Tel.: +7 (499) 374-75-31. E-mail: intrelation@mosgu.ru

\section{Для цитирования:}

Володин И. А. Международное молодежное и студенческое движение: этапы большого пути [Электронный ресурс] // Научные труды Московского гуманитарного университета. 2018. № 6. URL: http://journals.mosgu.ru/trudy/ article/view/837 (дата обращения: дд.мм.гг.). DOI: 10.17805/trudy.2018.6.6 